\title{
HUBUNGAN PENGETAHUAN DENGAN SIKAP IBU TERHADAP ASI EKSKLUSIF DI WILAYAH KERJA PUSKESMAS PEMBANTU KM 18 BENCAH KELUBI KAMPAR KIRI TAHUN 2011
}

\author{
Chairil, Dian Anggriani \\ Staf Pengajar F-MIPA dan Kesehatan UMRI \\ Alumni DIV Kebidanan STIKES AL-INSYIRAH Pekanbaru \\ E-mail: chairilkakfi@gmail.com
}

\begin{abstract}
ABSTRAK
Asi adalah suatu emulsi lemak dalam larutan protein, lactose dan garam-garam organik yang disekresi oleh kedua kelenjar payudara ibu, sebagai makanan utama bagi bayi. ASI eksklusif adalah ASI saja tanpa minuman lain termasuk air putih dan susu formula, tanpa makanan lain seperti bubur susu atau pisang kering, tetapi obat dan suplemen diperbolehkan. Penelitian ini bertujuan untuk mengetahui hubungan pengetahuan dengan sikap ibu terhadap pemberian ASI eksklusif dengan menggunakan metode survei deskriptif korelasi. Pengumpulan data didapatkan dari data primer dengan menyebarkan kuesioner dan analisa data dilakukan secara univariat dan bivariat dengan uji statistik chi square. Sampel yang digunakan dalam penelitian ini adalah 56 responden dan hasil penilitian menunjukkan bahwa sebanyak 34 (70,8\%) dari 48 responden yang berpengetahuan tinggi memberikan ASI eksklusif dan sebanyak $34(73,9 \%)$ dari 46 responden yang bersikap positif memberikan ASI eksklusif. Terdapat hubungan antara pengetahuan dengan ASI eksklusif dengan $\mathrm{p}$ value $=0,048$ dan terdapat hubungan antara sikap denganASI eksklusif dengan $\mathrm{p}$ value $=0,007$. Hasil penelitian menunjukkan bahwa terdapat hubungan antara pengetahuan dengan sikap ibu terhadap pemberian ASI eksklusif. Peneliti berharap agar dilakukan penyebaran informasi mengenai manfaat dan cara pemberian ASI yang baik dan benar kepada ibu yang memiliki bayi dan balita sehingga pemberian ASI eksklusif dapat lebih ditingkatkan.
\end{abstract}

Kata kunci: Pengetahuan, Sikap dan ASI Eksklusif

\section{PENDAHULUAN}

Bila setiap orang tua mampumenyadari akan pentingnya ASI eksklusif bagi bayi yang dilahirkan, maka masa depan generasi mendatang akan lebih baik dan berguna bagi orang tua, bangsa dan negera. Salah satunya untuk mewujudkan hal itu adalah dengan memberikan ASI eksklusif sejak dini. ASI eksklusif adalah bayi hanya diberi ASI saja tanpa tambahan cairan lain, dan tanpa tambahan makanan lain yang diberikan pada bayi sampai umur 6 bulan (Khasanah,2011).

Menurut Khairuniah (2004) yang di kutip oleh Gultom (2010) ASI merupakan sumber gizi yang sangat ideal dengan komposisi yang seimbang dan sesuai dengan kebutuhan pertumbuhan bayi, karena ASI adalah makanan bayi yang paling sempurna baik secara kualitas maupun kuantitas. ASI sebagai makanan tunggal akan mencukupi kebutuhan tumbuh kembang bayi normal sampai usia $4-6$ bulan (Yuliarti,2010).
ASI memiliki khasiat yang begitu besar, namun tidak banyak ibu yang mau atau bersedia memberikanASI eksklusif selama 6 bulan, seperti yang disarankan organisasi kesehatan dunia (WHO). Sentra laktasi Indonesia mencatat bahwa berdasarkan survey demografi dan kesehatan Indonesia 2002-2003, hanya 15\% ibu yang memberikan ASI eksklusif selama 5 bulan. ASI eksklusif di Indonesia rata- rata hanya di berikan hingga bayi berusia 2 bulan. Pada tahun 2005-2006, bayi di Amerika Serikat yang mendapatkan ASI eksklusif justru meningkat menjadi 60-70\% (Yuliarti, 2010).

Dari survei yang dilaksanakan pada tahun 2002 oleh Nutrition \& Heath Surveillance system (NSS) kerjasama dengan Balitbangkes dan Keller International di 4 perkotaan (Jakarta, Surabaya, Semarang, Makasar) dan 8 pedesaan (Sumbar, Lampung, Banten, Jabar, Jateng, Jatim, NTB, Sulsel), menunjukkan bahwa cakupan ASI eksklusif 4-5 bulan di perkotaan antara $14 \%-21 \%$, sedangkan di pedesaan $14 \%$ - 
26\%. Pencapaian ASI eksklusif 5-6 bulan di perkotaan berkisar antara 3\%-18\% sedangkan di pesesaan 6\%-19\%. Pada ibu yang bekerja, singkatnya masa cuti hamil/melahirkan mengakibatkan sebelum masa pemberian ASI eksklusif berakhir mereka sudah harus kembali bekerja. Hal ini mengganggu upaya pemberian ASI eksklusif (Kodrat, 2010).

Berdasarkan Profil Dinkes Kota Bandung yang dikutip oleh Gultom (2010) Semakin banyak ibu tidak memberikan ASI pada bayinya semakin menurun angka pemberian ASI terutama ASI eksklusif. Seperti data status kesehatan masyarakat Kota Bandung tahun 2005, ibu yang menyusui bayinya dengan ASI sebanyak $57.974(65,41 \%)$, dan yang diberikan ASI eksklusif dari 0-6 bulan tanpa makanan tambahan sebesar 39,37\%. Hal ini menunjukkan bahwa cakupan pemberian ASI eksklusif di kota Bandung masih rendah(kodrat,2010).

Berdasarkan survei awal yang dilakukan peneliti pada tanggal 30 mei 2011, di dapatkan data bahwa dari12 orang ibu yang memiliki bayi usia 6 bulan-2 tahun, didapat data bahwa hanya 4 orang atau sekitar $33.3 \%$ ibu yang memberikan ASI eksklusif kepada bayinya. Sebagian dari ibu-ibu tersebut tidak memberikan ASI secara eksklusif dikarenakan kesibukan mereka dalam bekerja dan juga dikarenakan takut bahwa bayinya akan kekurangan nutrisi.

Untuk mengatasi masalah tersebut, pemerintah membuat program-program yang dapat mendukung penggunaan ASI eksklusif antara lain melalui pemberian pendidikan kesehatan tentang pentingnya pemberian ASI eksklusif pada masyarakat. Penelitian-penelitian yang dapat menunjang program pemberian ASI eksklusif seperti tentang komposisi ASI juga terus dilakukan. Berdasarkan data yang di peroleh tersebu, peneliti tertarik untuk melakukan penelitian tentang "Hubungan Pengetahuan dan Sikap Ibu Menyusui Tentang Pemberian ASI Eksklusif pada Bayi Usia 0-6 bulan di Puskesmas Pembantu KM 18 Bencah Kelubi Kampar Kiri Tahun 2011”.

\section{METODOLOGI PENELITIAN}

Peneliti menggunakan desain penelitian deskriptif korelasi yaitu suatu metode penelitian yang bertujuan untuk melihat, membuat gambaran atau deskripsi tentang suatu keadaan secara objektif, dengan pendekatan yang digunakan yaitu studi korelasi (correlation study) yaitu penelitian antara dua variable pada situasi atau sekelompok subjek.

Populasi adalah wilayah generalisasi yang terdiri atas: objek/subjek yang mempunyai kuantitas dan karakteristik tertentu yang ditetapkan oleh peneliti untuk dipelajari dan kemudian ditarik kesimpulannya Populasi yang digunakan dalam penelitian ini adalah ibu yang memiliki bayi usia 6 bulan - 2 tahun yang ada di wilayah kerja Puskesmas Pembantu KM 18 Bencah Kelubi yaitu sebanyak 125 orang.

Sampel merupakan bagian populasi yang akan diteliti atau sebagian jumlah dari karakteristik yang dimiliki oleh populasi Besar sampel yang digunakan dalam penelitian ini adalah seluruh ibu yang memiliki bayi usia 6 bulan-2 tahun, sehingga di peroleh jumlah sampel sebanyak 56 orang.

Analisis yang di gunakan2 macam adalah Analisis Univariat Analisis univariat dilakukan untuk menggambarkan distribusi frekuensi masing-masing variable, baik variable bebas, variable terikat maupun deskripsi karakteristik responden.Analisis Bivariat Analisis bivariat dilakukan dengan mengguanakan uji chi square syarat uji chi square antara lain jumlah sampel cukup besar, pengamatan harus bersifat independen, dan hanya dapat digunakan pada data dekstrit/data kontinu yang telah dikelompokkan menjadi kategori.Dasar pengambilan keputusan penerimaan hipotesis berdasarkan tingkat signifikan (nilai) sebesar $95 \%$; Jika nilai $\mathrm{P}$ value $>(0,05)$ Ho diterima maka hipotesis penelitian (Ha) ditolak. Jika nilai $\mathrm{P}$ value $<(0,05)$ Ho ditolak maka hipotesis penelitian (Ha) diterima.

\section{HASIL DAN PEMBAHASAN}

1. Analisis Univariat

Analisis univariat digunakan untuk menggambarkan pemberian ASI ekslusifpada 
bayi usia 0 - 6 bulan terhadap pengetahuan dan sikap.

\section{Tabel 1.}

Distribusi Frekuensi Responden Berdasarkan Pendidikan Ibu yang Memiliki Bayi Usia 6 bulan-2 tahun di Wilayah Kerja Puskesmas Pembantu km 18 Bencah Kelubi

\begin{tabular}{ccc}
\hline Pendidikan & Frekuensi & Persentase (\%) \\
\hline SD & 26 & 46.4 \\
SMP & 15 & 26.8 \\
SMA & 12 & 21.4 \\
Sarjana & 3 & 5.4 \\
\hline Total & $\mathbf{5 6}$ & $\mathbf{1 0 0}$ \\
\hline
\end{tabular}

Tabel 2.

Distribusi Frekuensi Responden Berdasarkan Umur Ibu yang Memiliki Bayi Usia 6 bulan-2 tahun di Wilayah Kerja Puskesmas Pembantu km 18 Bencah Kelubi

\begin{tabular}{ccc}
\hline Umur & Frekuensi & Persentase (\%) \\
\hline 20-30 Tahun & 45 & 80.4 \\
31-40 Tahun & 11 & 19.6 \\
\hline Total & $\mathbf{5 6}$ & $\mathbf{1 0 0}$ \\
\hline
\end{tabular}

Tabel 3.

Distribusi Frekuensi Responden Berdasarkan Pekerjaan Ibu yang Memiliki Bayi Usia 6 bulan-2 tahun di Wilayah Kerja Puskesmas Pembantu km 18

\begin{tabular}{ccc}
\multicolumn{3}{c}{ Bencah Kelubi } \\
\hline Pe-kerjaan & Frekuensi & Persentase (\%) \\
\hline IRT & 50 & 89.3 \\
Petani & 1 & 1.8 \\
Wiraswasta & 5 & 8.9 \\
\hline Total & 56 & 100 \\
\hline
\end{tabular}

Tabel 4.

Distribusi Frekuensi Responden Berdasarkan Pengetahuan Ibu yang Memiliki Bayi Usia 6 bulan-2 tahun di Wilayah Kerja Puskesmas Pembantu km 18 Bencah Kelubi

\begin{tabular}{llll}
\hline No & Pengetahuan & Frekuensi & $\begin{array}{l}\text { Persentase } \\
(\%)\end{array}$ \\
\hline 1 & Tinggi & 48 & 85,7 \\
2 & Rendah & 8 & 14,3 \\
\hline \multicolumn{2}{l}{ Total } & 56 & 100 \\
\hline
\end{tabular}

Tabel 5.

Distribusi Frekuensi Responden Berdasarkan Sikap Ibu yang Memiliki Bayi Usia 6 bulan-2 tahun di Wilayah Kerja Puskesmas Pembantu km 18 Bencah Kelubi

\begin{tabular}{llll}
\hline No & Sikap & Frekuensi & $\begin{array}{l}\text { Persentase } \\
(\%)\end{array}$ \\
\hline 1 & Positif & 46 & 82,14
\end{tabular}

\begin{tabular}{llll}
\hline No & Sikap & Frekuensi & $\begin{array}{l}\text { Persentase } \\
(\%)\end{array}$ \\
\hline $\mathbf{2}$ & Negatif & $\mathbf{1 0}$ & $\mathbf{1 7 , 8 6}$ \\
\hline Total & $\mathbf{5 6}$ & $\mathbf{1 0 0}$ \\
\hline
\end{tabular}

Tabel 6.

Distribusi Frekuensi Responden Berdasarkan

Pemberian ASI Eksklusif di Wilayah Kerja

Puskesmas Pembantu km 18 Bencah Kelubi.

\begin{tabular}{|c|c|c|c|}
\hline No & $\begin{array}{l}\text { Pemberian } \\
\text { ASI }\end{array}$ & Frekuensi & $\begin{array}{l}\text { Persentase } \\
(\%)\end{array}$ \\
\hline & $\begin{array}{l}\text { ASI } \\
\text { Eksklusif }\end{array}$ & 38 & 67,9 \\
\hline 2 & $\begin{array}{l}\text { Tidak ASI } \\
\text { Eksklusif }\end{array}$ & 18 & 32,1 \\
\hline Tot & & 56 & 100 \\
\hline
\end{tabular}

\section{Analisis Bivariat}

a. Hubungan pengetahuan ibu terhadap pemberian ASI eksklusif pada bayi usia 0-6 bulan di wilayah kerja Puskesmas Pembantu km 18 Bencah Kelubi

Tabel 7.

Hubungan Pengetahuan Ibu Terhadap Pemberian ASI Eksklusif pada Bayi Usia 0-6 Bulan di Wilayah Kerja Puskesmas Pembantu km 18 Bencah Kelubi.

\begin{tabular}{|c|c|c|c|c|c|}
\hline \multirow[b]{2}{*}{ No } & \multirow[b]{2}{*}{ Pengetahuan } & \multicolumn{2}{|c|}{ Pemberian ASI } & \multirow[b]{2}{*}{ Total } & \multirow[b]{2}{*}{$\begin{array}{c}\mathrm{P} \\
\text { value }\end{array}$} \\
\hline & & $\begin{array}{l}\text { Tidak } \\
\text { ASI } \\
\text { Eksklusif }\end{array}$ & $\begin{array}{l}\text { ASI } \\
\text { Eksklusif }\end{array}$ & & \\
\hline 1 & Rendah & $\begin{array}{l}4 \\
(50,0 \%)\end{array}$ & $\begin{array}{l}4 \\
(50,0 \%)\end{array}$ & $\begin{array}{l}8 \\
(100,0 \%)\end{array}$ & \\
\hline 2 & Tinggi & $\begin{array}{l}14 \\
(29,2 \%)\end{array}$ & $\begin{array}{l}34 \\
(70,8 \%)\end{array}$ & $\begin{array}{l}48 \\
(100,0 \%)\end{array}$ & 0,048 \\
\hline Total & & $\begin{array}{l}18 \\
(32,1 \%)\end{array}$ & $\begin{array}{l}38 \\
(67,9 \%)\end{array}$ & $\begin{array}{l}56 \\
(100,0 \%) \\
\end{array}$ & \\
\hline
\end{tabular}

Tabel 8.

Hubungan Sikap Ibu Terhadap Pemberian ASI Eksklusif pada Bayi Usia 0-6 Bulan di Wilayah Kerja Puskesmas Pembantu km 18 Bencah Kelubi

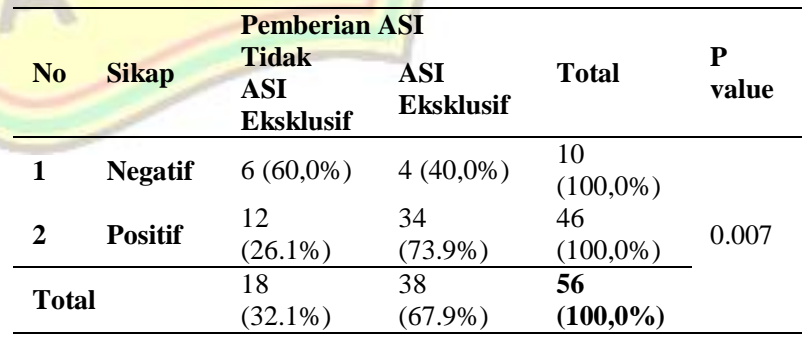


Tabel 9.

Hubungan Pengetahuan dengan Sikap Ibu Terhadap Pemberian ASI Eksklusif pada Bayi Usia 0-6 Bulan di Wilayah Kerja Puskesmas Pembantu km 18 Bencah Kelubi

\begin{tabular}{|c|c|c|c|c|c|}
\hline $\begin{array}{l}\mathbf{N} \\
\mathbf{0}\end{array}$ & $\begin{array}{l}\text { Pengetah } \\
\text { uan }\end{array}$ & $\begin{array}{l}\text { Sikap Ibu } \\
\text { Negatif }\end{array}$ & Positif & Total & $\begin{array}{l}\mathbf{P} \\
\text { val } \\
\text { ue }\end{array}$ \\
\hline 1 & Rendah & $3(37,5 \%)$ & $5(62,5 \%)$ & $8(100,0 \%)$ & \multirow{3}{*}{$\begin{array}{l}0,02 \\
3\end{array}$} \\
\hline 2 & Tinggi & $7(14,6 \%)$ & $\begin{array}{l}41 \\
(85,4 \%)\end{array}$ & $\begin{array}{l}48 \\
(100,0 \%)\end{array}$ & \\
\hline \multicolumn{2}{|c|}{ Total } & $\begin{array}{l}10 \\
(17,9 \%)\end{array}$ & $\begin{array}{l}46 \\
(82,1 \%)\end{array}$ & $100,0 \%)$ & \\
\hline
\end{tabular}

\section{Analisa Univariat}

1. Umur Ibu terhadap ASI Eksklusif

Berdasarkan data yang diperoleh dari hasil penelitian, di dapatkan bahwa dari kelompok umur ibu 20-30 tahun sebanyak 31 (68,9\%) dari 45 responden yang memberikan ASI eksklusif. Sementara rentang umur ibu yang berusia 31-40 tahun sebanyak $7(63,6 \%)$ dari 11 responden yang memberikan ASI eksklusif.

Berdasarkan data hasil penelitian, menunjukkan angka yang cukup signifikan. Dapat disimpulkan bahwa tidak ada hubungan antara umur ibu terhadap pemberian ASI Eksklusif.

2. Pekerjaan Ibu Terhadap ASI Eksklusif

Berdasarkan data yang diperoleh mengenai pekerjaan, mayoritas berprofesi sebagai ibu rumah tangga (IRT) yaitu sebanyak 50 responden $(89,3 \%)$. Dengan kata lain dapat disimpulkan bahwa ada hubungan status pekerjaan dengan prilaku menyusui eksklusif. Hal ini dapat juga di kaitkan dengan ketersediaan waktu ibu rumah tangga yang lebih banyak di rumah dalam menyusui eksklusif. Pekerjaan merupakan alasan yang sering digunakan oleh ibu untuk berhenti menyusui bayinya. Di daerah perkotaan, ibu banyak turut bekerja mencari nafkah, sehingga tidak dapat menyusui bayinya secara teratur. Sebenarnya walaupun ibu bekerja, ibu masih bisa untuk dapat memberikan ASI kepada bayinya (Roesli dalam Elinofia, 2011). Menurut peneliti, sebagian ibu yang meyoritas bekerja sebagai ibu rumah tangga memiliki waktu yang lebih banyak di rumah, sehingga berpeluang lebih besar untuk memberikan ASI eksklusif pada bayinya.

3. Pendidikan Ibu Terhadap ASI Eksklusif

Berdasarkan hasil penelitian, di peroleh hasil bahwa sebanyak $17 \quad(65,4 \%)$ dari 26 responden pendidikan terakhirnya SD yang memberika ASI Eksklusif, dan sebanyak 12 (80\%) dari 15 responden yang memberikan ASI Eksklusif.

Pendidikan adalah suatu kegiatan untuk meningkatkan pengetahuan. Pendidikan dapat diperoleh ibu secara formal, informal, dan non formal. Dengan demikian semakin tinggi tingkat pendidikan ibu maka semakin mudah ibu itu untuk memperoleh informasi. Ibu yang memiliki pengetahuan yang kurang tentang menyusui dan pentingnya pemberian ASI merupakan salah satu faktor yang menyebabkan rendahnya motivasi ibu dalam pemberian ASI kepada bayinya. Sedangkan ibu yang mempunyai bekal pengetahuan yang benar tentang ASI dan status gizi bayi berpeluang lebih besar untuk menjaga motivasi menyusui bayinya. Pendidikan seorang ibu yang rendah memungkinkan ia lambat dalam mengadopsi pengetahuan baru, khususnya tentang hal-hal yang berhubungan dengan pola pemberian ASI.

4. Pengetahuan Ibu Terhadap ASI Eksklusif

Berdasarkan hasil penelitian dapat disimpulkan bahwa terdapat hubungan antara pengetahuan terhadap pemberian ASI eksklusif.

Pengetahuan adalah kesan di dalam fikiran manusia sebagai hasil penggunaan panca inderanya. Menurut Notoadmodjo (2003) bahwa pernah atau tidak pernahnya seseorang memperoleh informasi berpengaruh terhadap pengetahuan orang tersebut. Tingginya pengetahuan seseorang tidak hanya di ukur dari tingkat pendidikannya tetapi juga dari banyaknya informasi yang mereka peroleh.

Berdasarkan penelitian yang telah dilakukan, diperoleh informasi bahwa sebanyak 52 responden $(92,9 \%)$ ibu tahu mengenai ASI eksklusif. Dengan demikian, rata-rata responden sudah memiliki 
pengetahuan yang baik mengenai ASI sehingga mau memberikan ASI eksklusif pada bayi hingga usia 6 bulan

5. Sikap Ibu Terhadap ASI Eksklusif

Berdasarkan penelitian yang telah dilakukan diperoleh hasil bahwa mayoritas responden memiliki sikap positif yaitu sebanyak 46 responden $(82,14 \%)$ sedangkan yang memiliki sikap negatif yaitu sebanyak 10 responden $(17,86 \%)$.

Menurut asumsi peneliti, sikap positif yang memberikan ASI eksklusif pada bayi dilakukan karena ibu memiliki pengetahuan yang baik dan memiliki lebih banyak waktu di rumah sehingga mampu untuk lebih fokus memberikan ASI eksklusif pada bayinya.

\section{Analisis Bivariat}

Hasil penelitian menunjukkan bahwa terdapat hubungan antara pengetahuan terhadap pemberian ASI eksklusif. Pengetahuan atau kognitif merupakan domain yang sangat penting untuk terbentuknya tindakan seseorang.

Hasil penelitian menunjukkan bahwa semakin tinggi pengetahuan yakni dari 48 responden maka semakin banyak ibu memberikan ASI eksklusif yaitu sebanyak 34 responden $(70,8 \%)$. Sementara pada variable sikap menunjukkan bahwa sikap positif dapar mempengaruhi ibu dalam pemberian ASI eksklusif. Hal ini di dukung dari hasil penelitian yakni dari 46 responden yang bersikap positif terdapat 34 responden atau sebesar $73,9 \%$ yang memberikan ASI eksklusif.

\section{A. Keterbatasan Penelitian}

1. Keterbatasan Rancangan Penelitian

Penelitian ini menggunakan metode survey deskriptif, peneliti hanya diarahkan untuk mendeskripsikan dan menguraikan suatu keadaan di suatu komunitas. Penelitian ini hanya menyuguhkan sedeskriptif mungkin mengenai hubungan pengetahuan dan sikap terhadap ASI eksklusif tanpa mencoba menganalisis lebih dalam mengenai ASI eksklusif.

2. Keterbatasan Waktu dan Tenaga dari Peneliti

Masih banyak faktor-faktor lain yang berhubungan dengan ASI eksklusif yang dapat dijadikan sebagai variabel bebas dalam penelitian ini. Namun karena kemampuan penulis terbatas dalam hal waktu dan tenaga maka penulis hanya membahasnya secara univariat dan bivariat.

3. Keterbatasan Alat Pengumpul Data

Pengumpulan data menggunakan kuisioner mempunyai dampak yang sangat subyektif sehingga kebenaran data tergantung pada kejujuran dari responden. Peneliti belum menemukan standar baku kuisioner sehingga instrument tersebut dibuat berdasarkan pemahaman dan pengalaman dari peneliti sendiri yang tentunya masih terbatas sebagai peneliti pemula dan beberapa dari kepustakaan.

4. Keterbatasan Validitas Instrumen Penelitian

Kuisioner baru pertama kali digunakan meskipun hasil uji validitas sudah cukup baik namun baru terbatas pada satu wilayah kerja puskesmas sehingga akan menjadi lebih valid apabila dilakukan uji coba pada wilayah kerja puskesmas lainnya.

\section{DAFTAR PUSTAKA}

Februhartanty, J., (2009).ASI: Dari Ayah Untuk Ibu dan Bayi. Jakarta: Semesta Medika.

Khasanah, N., (2011). ASI atau Susu Formula Ya. Yogyakarta: Flashbook.

Kodrat, L., (2010). Dahsyatnya ASI \& Laktasi. Yogyakarta: Media Baca.

Notoatmodjo, S. (2002). Promosi kesehatan dan ilmu prilaku. Jakarta: Rineka cipta

Notoatmodjo, S., (2003). Pendidikan Dan Ilmu Perilaku. Jakarta. Rineka cipta

Notoatmodjo, S., (2007). Kesehatan Masyarakat: Ilmu \& Seni. Jakarta: Rineka Cipta.

Notoatmodjo, S., (2010). Metodologi Penelitian Kesehatan. Jakarta: Rineka Cipta.

Nugroho, T., (2011). ASI dan Tumor Payudara. Yogyakarta: Nuha Medika.

Riyanto, Agus. (2009). Pengolahan dan analisis data kesehatan. Yogyakarta: Nuha Medika

Setiawan, dkk., (2010). Metodologi Penelitian Kebidanan. Yogyakarta: Mutia Medika. 
Sugiyono, (2005). Metode Penelitian administrasi. Bandung: Alfabeta

Yuliarti, N., (2010). Keajaiban ASI-Makanan Terbaik Untuk Kesehatan, Kecerdasan dan Kelincahan Si Kecil. Yogyakarta: Penetbit Andi.

Panduan Skripsi. (2010). Universitas Sumatera Utara, Medan.
(2010). Ilmu perilaku kesehatan. Jakarta: Rineka cipta (2010). Metodologi penelitian. Jakarta: Rineka cipta

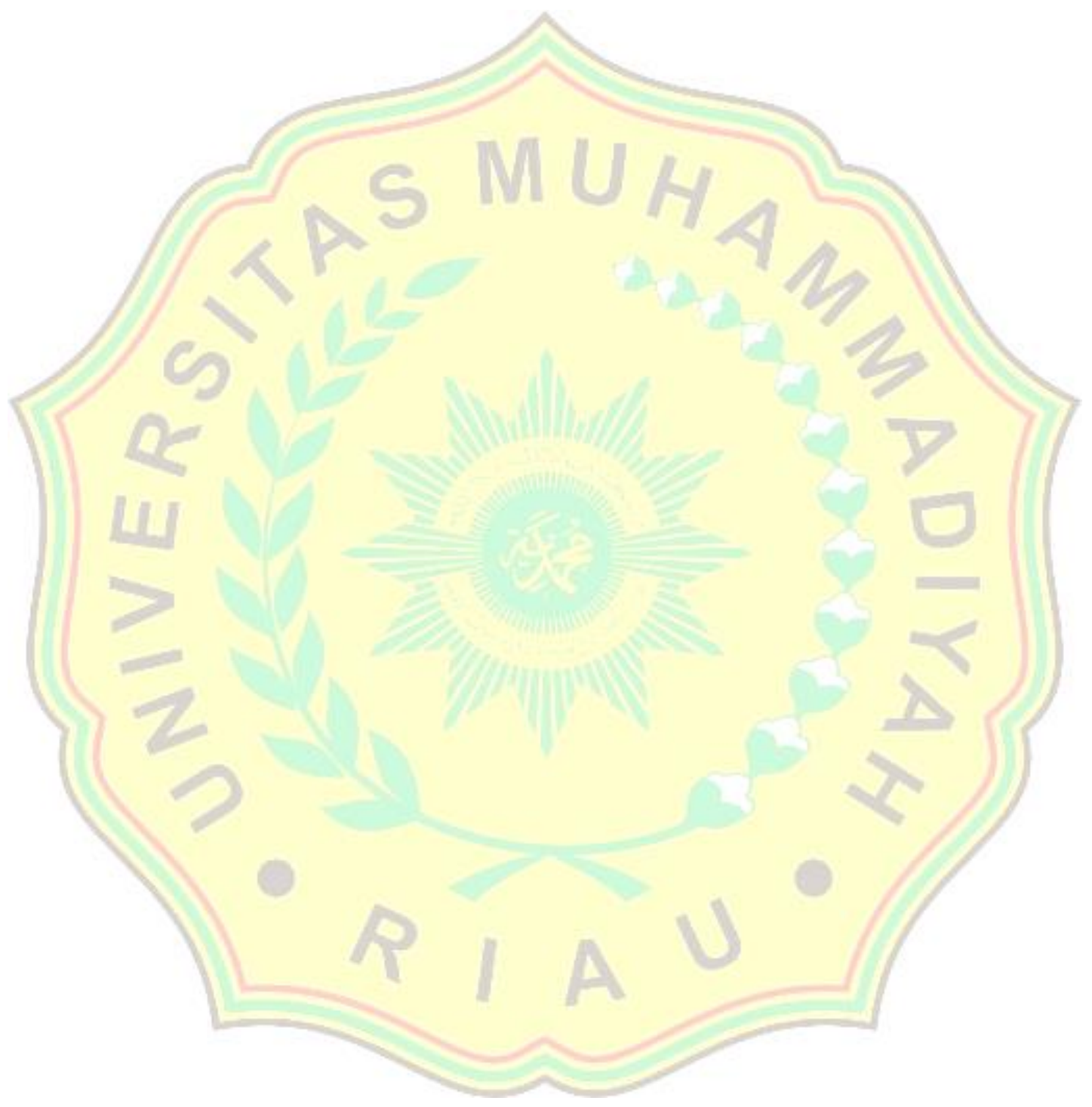

